\title{
Classical and Molecular Genetic Studies of the Strong Greenish Yellow Seedcoat Color in 'Wagenaar' and 'Enola' Common Bean
}

\author{
Mark J. Bassett ${ }^{1}$ \\ Horticultural Sciences Department, University of Florida, Gainesville, FL 32611 \\ Rian Lee, ${ }^{2}$ Carla Otto, ${ }^{3}$ and Phillip E. McClean ${ }^{1}$ \\ Department of Plant Sciences, North Dakota State University, Fargo, ND 58105-5051
}

AdDitional INDEX wORDS. Phaseolus vulgaris, seedcoat genetics, RAPD markers, Mayocoba dry beans

\begin{abstract}
Inheritance of the strong greenish-yellow (SGY) seedcoat color in 'Wagenaar' common bean (Phaseolus vulgaris $\mathbf{L}$.) was investigated. Line 5-593 is a determinate, Florida dry bean breeding line (with small black seeds) used as the recurrent parent in the development of many genetic stocks, e.g., $g b v \mathrm{BC}_{3}$ 5-593. Through crosses with genetic tester stocks, the seedcoat genotype of 'Wagenaar' was confirmed to be $C J g b v^{\text {lae }} R k$. Three randomly amplified polymorphic DNA markers $\left(O A P 7_{850}, O A P 3_{1400}\right.$, and OU14 $\left.{ }_{950}\right)$ that cosegregated with the $G$ seedcoat color locus were developed from the $\mathrm{F}_{2}$ population derived from the cross $g b v \mathrm{BC}_{2} 5-593 \times G b v \mathrm{BC}_{3}$ 5-593. From the cross 'Wagenaar' $\times g b v \mathrm{BC}_{3} 5-593$, $80 \mathrm{~F}_{2}$ plants were classified into 54 non-SGY and 16 SGY seedcoat color plants. When the OAP7 $7_{850}$ marker was applied to that population, linkage was not observed with the non-SGY and SGY phenotypes. Conversely, a molecular marker $\left(\mathrm{OAP12}_{400}\right.$, that was developed from the $\mathrm{F}_{2}$ from the cross 'Wagenaar' $\mathrm{x} g \boldsymbol{b} v \mathbf{B C}_{3}$ 5-593) linked to the locus controlling the SGY phenotype segregated independently of the $G$ locus. Therefore, SGY phenotype is not controlled by the $G$ locus. $A n F_{3}$ progeny test of $76 \mathrm{~F}_{2}$ plants from the cross 'Wagenaar' $\mathrm{x} g \boldsymbol{b} v \mathrm{BC}_{3}$ 5-593 confirmed the hypothesis that a single recessive gene (for which we propose the symbol $g y$ ) controls the seedcoat color change from pale greenish yellow (PGY) to SGY. Through crosses with genetic tester stocks, the seedcoat genotype of 'Enola' was determined to be $C J g b v^{\text {lae }} R k$. The test cross 'Enola' $x$ 'Wagenaar' demonstrated that 'Enola' also carries the $g y$ gene. The relationship of 'Enola' to the 'Mayocoba' market class of common bean and to 'Azufrado Peruano 87' is discussed.
\end{abstract}

Prakken (1970) summarized the genetics of seedcoat colors in common bean (Phaseolus vulgaris) other than red colors, and he reconciled the various systems of gene symbols used by various researchers. Subsequently, Prakken (1972) published his extensive work with red seedcoat colors and organized the entire body of seedcoat color genetics (Prakken, 1970, 1972) into two tables, one for the yellow-black series of colors and the other (a text table) for the red colors. One of the colors in the first table is pale greenish yellow (canary), which was also called schamois by Lamprecht (1932). The genotype of pale greenish yellow is $P C J g b v R k$. The seedcoat color investigated in the present paper is a very much more intense color, which we will designate as strong greenish yellow (SGY).

The seedcoat genotype of 'Wagenaar' was studied by Prakken (1940) in the cross 'Wagenaar' X 'Citroen' and found to be P C D $J g b v^{\text {lae }}$ (using the gene symbols of Prakken, 1970). In subsequent work, Prakken (1972) used 'Wagenaar' in two diallel crossing sets of four parents each, and he analyzed the 12 resulting $F_{2}$ progenies. This work confirmed the previous genotype for seedcoat color, which is described as "shiny pale greenish yellow" with purple corona. The purple corona trait is controlled by the $v^{\text {lae }}$ gene (Bassett, 1995a).

Prakken (1940) described 'Wagenaar' as a two-toned seedcoat (canary and schamois), which he interpreted as being always typical

\footnotetext{
Received for publication 18 Apr. 01. Accepted for publication 5 Sept. 2001. This research was supported by the Florida Agricultural Experiment Station and a TSTAR grant, and approved for publication as journal series no. N-01969. The cost of publishing this paper was defrayed in part by the payment of page charges. Under postal regulations, this paper therefore must be hereby marked advertisement solely to indicate this fact.

${ }^{1}$ Professor.

${ }^{2}$ Technician.

${ }^{3}$ Undergraduate student.
}

of the seedcoat genotype $P C J g b v$ (or $v^{\text {lae }}$ ). The senior author of this paper has never observed expression of the canary yellow seedcoat color in the genetic stock $g b v \mathrm{BC}_{3}$ 5-593, which he describes as (very) pale greenish yellow (PGY). In this paper the canary color of Prakken (1940) will be called SGY.

When 'Wagenaar' is grown in the greenhouse at Gainesville, Fla., or Fargo, N. Dak., the distribution of SGY on the seedcoats of 'Wagenaar' is often incomplete, i.e., part of the seedcoat has PGY and the remainder SGY. Our observations for two-toned color pattern are the same as those of Prakken (1940), but our genetic interpretation is different. We hypothesize that the genotype $C J g$ $b v$ gives schamois to (very) pale greenish yellow, but never the SGY (canary) that Prakken (1940) observed in 'Wagenaar.' Furthermore, we hypothesize that an independent gene (tentative symbol Gy) with variable expressivity intensifies PGY to SGY in 'Wagenaar.' The same SGY color of 'Wagenaar' occurs with variable expressivity in the 'Mayocoba' market class of dry (common) bean (Bassett, unpublished observation). 'Enola', a patented dry bean cultivar, also has the SGY color with variable expressivity as shown in the color photograph included in the patent (Proctor, 1999). Therefore, the objectives of this work were to 1) determine the inheritance of SGY seedcoat color, 2) reexamine the full seedcoat genotype of 'Wagenaar', 3) test alternative hypotheses that propose that SGY is produced either by a mutant allele at the $G$ (yellow seed color) locus or by a gene independent of $G$, using a combination of classical and molecular genetic approaches, 4) determine the seedcoat genotype of 'Enola' and the 'Mayocoba' market class, and 5) discuss the claims of the 'Enola' patent in relation to the findings of this paper.

\section{Materials and Methods}

Eight genes control seedcoat color in common bean, and very complicated epistatic interactions occur among those genes 
(Prakken, 1972). For this paper, only a brief introduction to the genetics of seedcoat color is needed. The cultivars tested in this paper all carried the dominant (wild type) allele at the $P, C, J$, and $R k$ loci, and those dominant alleles do not alter the color. Similarly, the cultivars tested all carried the recessive $r$ allele at the $R$ locus for dominant red color, which is closely linked to $C$. The genes $G, B$, and $V$ are color modifying genes: $G$ (from Gelbe, a German word) for yellow with $G b v, B$ for mineral brown with $G B v$, and $V$ for violet to black (anthocyanin pigments) with $G B$ $V$. With $g b v$, the seedcoat is nearly colorless, shamois to (very) pale greenish yellow or cream color. This paper presents evidence for a ninth seedcoat color gene expressing SGY in the $P[C r] J$ $g b v R k$ genetic background.

Seeds of 'Wagenaar' were obtained from H. Dijkstra, Collection Manager, Centre for Genetic Resources, Wageningen, The Netherlands. Prakken (1940) described a difference in the color of 'Wagenaar' 'between the hilum side and the opposite dorsal (and lateral) side of the seed" as being characteristic. The hilum (ventral) side was canary yellow, whereas the dorsal side was schamois. The two color zones were not sharply separated, and transitional colors occurred. Prakken (1940) goes on to comment, "The canary yellow is extremely variable in its extension, even in seeds on the same plant; sometimes it is nearly imperceptible or restricted to very small ventral spots in the region of the germ root and near the caruncula; in other cases nearly the whole seedcoat can show the color." This exact and detailed description fits perfectly the observed seedcoat color of 'Wagenaar' when grown at Gainesville, Fla., or Fargo, N. Dak.

Seeds of the 'Mayocoba' market class were obtained from the Los Angeles market by a source that cannot be disclosed due to contractual agreement. Seeds of 'Enola' were obtained from Mark Brick, Colorado State University, Fort Collins. Our dry bean breeding line 5-593 (Florida) has small seed size, with shiny black seedcoats of genotype $T P[C r] D J G B V R k$ (Bassett, 1994, 1996a; Bassett and Blom, 1991; Prakken, 1970). Genetic tester stocks were developed by using 5-593 as the recurrent parent in backcrossing programs (with $\mathrm{F}_{2}$ selection in each cycle) to transfer recessive genes, singly and in combination, into this standard genetic background. The genetic tester stocks used as testcross parents with 'Wagenaar' and 'Enola' are listed and described in Table 1.

Development of the genetic tester stock $g b v \mathrm{BC}_{3} 5-593$ began with a cross of 'Calima' ([C $\left.\left.{ }^{\text {ma }} R\right] J g b v R k\right)$ with $G b v \mathrm{BC}_{2} 5-593$ (Bassett, unpublished data). From this cross, a true breeding $\mathrm{F}_{3}$ progeny was developed with PGY seedcoat color ([Cr] $J g b v)$.
This $\mathrm{F}_{3}$ was crossed with $G b v \mathrm{BC}_{3} 5-593$ to create $g b v \mathrm{BC}_{1} 5$ 593. In a similar manner, two additional backcrosses (with $\mathrm{F}_{2}$ selection in each cycle) to $G b v \mathrm{BC}_{3} 5-593$ were used to create $g$ $b v \mathrm{BC}_{3}$ 5-593 in Spring 1997.

Over the past several years, the genetic tester stocks $\mathrm{P}_{3}, \mathrm{P}_{5}, \mathrm{P}_{6}$, $\mathrm{P}_{8}$, and $\mathrm{P}_{9}$ (Table 1) were all crossed with 'Wagenaar', and the $\mathrm{F}_{1}$ progeny of the test crosses were grown in the greenhouse at Gainesville, Fla., to produce the most complete expression of the seedcoat genes involved. Data were recorded for flower color and seedcoat color and pattern of the $\mathrm{F}_{2}$ seed produced. During the greenhouse season of 1999-2000, 'Enola' was crossed with genetic tester stocks $\mathrm{P}_{1}, \mathrm{P}_{3}, \mathrm{P}_{4}, \mathrm{P}_{7}$, and $\mathrm{P}_{9}$ (Table 1 ), and the $\mathrm{F}_{1}$ progeny of the test crosses were grown in the greenhouse at Gainesville, Fla. The $F_{2}$ progeny of the 'Enola' test crosses were grown in the field in Spring 2000. Flower color and seedcoat color and pattern phenotypes of the parental, $\mathrm{F}_{1}, \mathrm{~F}_{2}$, and $\mathrm{F}_{3}$ seed were recorded. Plants of 'Mayocoba' were grown in the greenhouse along side 'Enola' plants in 1999. Plant type and seed color data were recorded and used to further compare 'Mayocoba' and 'Enola'.

Test crosses for allelism of the SGY seedcoat color were made between 'Wagenaar' $x$ 'Mayocoba' and 'Enola' $x$ 'Wagenaar', and the $F_{1}$ progeny were grown in the greenhouse at Gainesville, Fla. Data were recorded on seedcoat color. From the cross 'Enola' $x$ 'Wagenaar', seeds were harvested from $10 \mathrm{~F}_{2}$ plants (bulked seed) selected for full SGY seedcoat color development. The SGY seedcoat color was characterized using two methods: 1) the Munsell Book of Color (1966 edition, 2.5R-10G, Munsell Color Co., Inc., Baltimore, Md.) and 2) a chromameter (model CR-200; Minolta, Ramsey, N. J.). For the latter technique, a seed sample was placed on a black table top as background. Data were recorded for both methods of characterization of SGY color.

The cross 'Wagenaar' $\mathrm{x} g b v \mathrm{BC}_{3}$ 5-593 was made and $80 \mathrm{~F}_{2}$ plants were grown in the greenhouse at Fargo, N. Dak. All seeds from each $\mathrm{F}_{2}$ plant were harvested. The plants were also classified for flower color and seedcoat pattern. A complete genetic model for the phenotypic data was developed, and the genetic segregation data were analyzed using the orthogonal contrasts of Mather (1957). Genetic linkage was calculated by the maximum likelihood method and tables of Allard (1956).

All seeds from each $\mathrm{F}_{2}$ plant from the cross 'Wagenaar' $\mathrm{x} g b$ $v \mathrm{BC}_{3}$ 5-593 were planted in the field at Gainesville, Fla., in Spring 2000 to achieve an $\mathrm{F}_{3}$ progeny analysis of the $\mathrm{F}_{2}$. Due to variable expressivity of the SGY trait, the seed sampling procedure varied depending on the phenotype of the $F_{2}$ parent. Prog-

Table 1. Seedcoat phenotypes and genotypes of 'Wagenaar' and 'Enola' and the genetic stocks used in testcrosses to determine the seedcoat genotype of 'Wagenaar' and 'Enola' common bean.

\begin{tabular}{|c|c|c|c|c|}
\hline \multirow{2}{*}{$\begin{array}{l}\text { Parent } \\
\text { no. }\end{array}$} & \multirow{2}{*}{$\begin{array}{l}\text { Stock } \\
\text { name }\end{array}$} & \multicolumn{2}{|l|}{ Seedcoat color } & \multirow[b]{2}{*}{ Reference } \\
\hline & & Phenotype & Genotype & \\
\hline$\overline{\mathrm{P}_{1}}$ & Wagenaar & Strong greenish yellow with purple corona & $P C D J g b v^{\text {lae }}$ & Prakken, 1972 \\
\hline $\mathrm{P}_{2}$ & Enola & Strong greenish yellow & Unknown & \\
\hline $\mathrm{P}_{3}$ & $c^{\mathrm{u}} \mathrm{BC}_{3} 5-593$ & Cartridge buff & $P c^{\mathrm{u}} D J G B V$ & Bassett, 1996a \\
\hline $\mathrm{P}_{4}$ & $c^{\mathrm{u}} b v r k^{\mathrm{d}} \mathrm{BC}_{1} 5-593$ & Dark red kidney & $P c^{\mathrm{u}} D J G b v r k^{\mathrm{d}}$ & Bassett, unpublished \\
\hline $\mathrm{P}_{5}$ & {$[c R] b v \mathrm{BC}_{3} 5-593$} & Oxblood red & $P[c R] D J G b v$ & Bassett, 1996b \\
\hline $\mathrm{P}_{6}$ & $j \mathrm{BC}_{3} 5-593$ & Dull dark purple with margo pattern ${ }^{\mathrm{z}}$ & $P C D j G B V$ & Bassett, 1996a \\
\hline $\mathrm{P}_{7}$ & $d j \mathrm{BC}_{3} 5-593$ & Dull dark purple with white hilum ring and corona & $P C d j G B V$ & Bassett, 1996a \\
\hline $\mathrm{P}_{8}$ & $G b v \mathrm{BC}_{3} 5-593$ & Yellow brown & $P C D J G b v$ & Bassett, 1995b \\
\hline $\mathrm{P}_{9}$ & $g b v \mathrm{BC}_{3} 5-593$ & Pale greenish yellow & $P C D J g b v$ & \\
\hline
\end{tabular}

${ }^{\mathrm{z}}$ Margo pattern has colored hilum ring, white (or nearly white) corona, and greater loss of dark purple color on the dorsal side of the seed than on the ventral side. 
Table 2. Results of testcrosses between 'Wagenaar' common bean and a series of genetic stocks with known seedcoat genotypes.

\begin{tabular}{ll}
\hline \hline Testcross $^{z}$ & Phenotype of seedcoats of seeds on $\mathrm{F}_{1}$ plants from the testcross \\
\hline $\mathrm{P}_{1} \times \mathrm{P}_{3}$ & Black/cartridge buff marbled \\
$\mathrm{P}_{1} \times \mathrm{P}_{5}$ & $\begin{array}{c}\text { Red/yellow brown (with red haze) mottle (subtle). At first glance the seed looks all red like the tester. A low contrast mottle pattern } \\
\text { not typical for the } C /[c R] \text { interaction, i.e., this is a true } C / c \text { mottle. }\end{array}$ \\
$\mathrm{P}_{1} \times \mathrm{P}_{6}$ & Shiny black seed (no margo pattern) \\
$\mathrm{P}_{1} \times \mathrm{P}_{8}$ & Violet (yellow brown with reddish haze)/pale yellow brown mottle (very subtle); purple corona \\
$\mathrm{P}_{1} \times \mathrm{P}_{9}$ & Pale violet/pale greenish yellow mottle; purple corona
\end{tabular}

${ }^{\bar{z}}$ The names, phenotypes, and genotypes of the parental lines $\left(\mathrm{P}_{\mathrm{i}}\right)$ are given in Table 1.

enies from $\mathrm{PGY} \mathrm{F}_{2}$ parents had only one pod sampled and a single seed selected for the composite for that plot. Progenies from SGY $\mathrm{F}_{2}$ parents had all pods harvested, and the entire seed production of each plant was classified for seedcoat color by scoring all seeds individually. $\mathrm{F}_{3}$ plants that produced any seeds with SGY color were classified as SGY. There were $76 \mathrm{~F}_{3}$ progenies grown, including a total of 670 plants. The mean $\mathrm{F}_{3}$ consisted of 8.8 plants, with the range of 1 to 27 plants.

Following the procedures of Brady et al. (1998), randomly amplified polymorphic DNA (RAPD) markers were developed for two seedcoat color genes: $G$ and a putative new gene controlling SGY color and tentatively given the symbol $G y$. The $G$ locus markers were developed from the $\mathrm{F}_{2}$ from the cross $g b v \mathrm{BC}_{2} 5$ $593 \times G b v \mathrm{BC}_{3} 5-593\left(\mathrm{P}_{8}\right)$. The genetic stock $g b v \mathrm{BC}_{2} 5-593$ is an earliler backcross version of $\mathrm{P}_{9}$ (Table 1). A RAPD marker for the $G y$ locus was developed from the $\mathrm{F}_{2}$ population of the 'Wagenaar' $\mathrm{x} g b v \mathrm{BC}_{3} 5-593$ cross described above.

\section{Results and Discussion}

Characterization of Sgy Seedcoat color. The observed color descriptors of the color tiles in the Munsell Book of Color most closely resembling the bulked seed sample from selected $F_{2}$ plants from the cross 'Enola' $x$ 'Wagenaar' ranged from $5 Y$ 8/6 to $8 / 10$ and $7 / 8$ to $7 / 10$, and $7.5 Y 8 / 6$ to $8 / 8$ and $7 / 10$. Those values describe the stronger greenish yellow of our selected seed materials compared with the paler greenish yellow of the seed materials described in the 'Enola' patent (Proctor, 1999). Using the same seed sample with the Minolta Chroma Meter, the objective color values recorded were $\mathrm{L}=52.87, \mathrm{C}=36.13$, and $\mathrm{H}=86.9$.

A NEW LOCUS fOR SGY vs. A MUTANT $\boldsymbol{G}$ GENE. Before this research, two competing hypotheses existed regarding the SGY seedcoat color phenotype. One hypothesis suggested the novel seedcoat color was the result of another allele at the classic $G$ gene. Alternatively, it was hypothesized that the SGY seedcoat color phenotype was the result of a new gene that modified the PGY seedcoat color phenotype. Our first approach to testing the alternative hypotheses was to develop molecular markers linked to $G$ and determine if they were linked to or cosegregated with the SGY phenotype.

An $\mathrm{F}_{2}$ population (derived from the cross $g b v \mathrm{BC}_{2} 5-593 \times G$ $b v \mathrm{BC}_{3}$ 5-593) segregating at $G$ was used to identify a RAPD linked to the gene. The population segregated for yellow-brown $\left(G_{-}\right)$and PGY $(g g)$ seedcoat color in the expected 3:1 phenotypic ratio $\left(\chi_{3: 1}^{2}=1.67, P=0.19\right)$ for this dominant-acting gene. Two bulks were created, each consisting of a pool of eight DNA samples from the yellow-brown or PGY seedcoat color classes. The DNA bulks were amplified by polymerase chain reaction (PCR) using a series of primers, and three primers were discovered that produced amplification patterns in which a fragment was present in the yellow-brown $\left(G_{-}\right)$but not the PGY $(g g)$ seedcoat color bulks. DNA from each member of the segregating population was amplified with the three primers, and the fragment segregation patterns were identical. Each individual in the population that contained the fragment was the $G_{-}$genotype, and each individual lacking the fragment was the $g g$ genotype. Recombination was not observed; and, therefore, the three marker fragments, $\mathrm{OAP} 7_{850}, \mathrm{OAP} 3_{1400}$, and $\mathrm{OU} 14_{950}$, appear to cosegregate with $G$. In addition, the three markers cosegregated with respect to each other.

The next experiment tested the linkage between one $G$-linked marker (OAP7 ${ }_{850}$ ) and the SGY seedcoat color phenotype. An $\mathrm{F}_{2}$ population from the cross 'Wagenaar' $\mathrm{x} g b v \mathrm{BC}_{3} 5-593\left(\mathrm{P}_{1} \times \mathrm{P}_{9}\right.$ of Table 2) segregated 3:1 for the PGY and SGY phenotypes (Table 3). Each individual in this population was scored for the presence and absence of the OAP7 ${ }_{850}$ marker. This $G$ marker and the two seedcoat color phenotypes segregated independently in this population. We, therefore, hypothesized that the genetic factor controlling the SGY seedcoat color was not $G$.

The next step was to develop a molecular marker linked to a gene for the SGY seedcoat color phenotype. A bulk segregant procedure, similar to that described above for the $G$ marker development, was used to discover marker OAP12 1400 that is linked in coupling with the dominant PGY phenotype. As described below, $\mathrm{F}_{2}$ individuals were genotypically classified using $\mathrm{F}_{3}$ family analysis. Using this data, the linkage between $G y$ and

Table 3. Segregation for seedcoat color in $\mathrm{F}_{2}$ and $\mathrm{F}_{3}$ from the cross 'Wagenaar' $\mathrm{x} g b v \mathrm{BC}_{3}$ 5-593 (pale greenish yellow tester).

\begin{tabular}{|c|c|c|c|c|c|c|c|}
\hline \multicolumn{3}{|c|}{$\mathrm{F}_{2}$ segregation } & \multicolumn{5}{|c|}{$\mathrm{F}_{3}$ segregation } \\
\hline $\begin{array}{l}\text { No. of } \\
\text { plants }^{z}\end{array}$ & $\begin{array}{c}\text { Seedcoat } \\
\text { color }\end{array}$ & $\begin{array}{c}\text { Genetic } \\
\text { hypothesis }\end{array}$ & $\begin{array}{c}\text { No. of } \\
\text { progenies }^{y}\end{array}$ & $\begin{array}{l}\mathrm{PGY}^{\mathrm{x}} \\
G y /-\end{array}$ & $\begin{array}{l}\mathrm{SGY}^{\mathrm{w}} \\
g y / g y\end{array}$ & $\begin{array}{c}\chi^{2} \\
3: 1\end{array}$ & $P$ \\
\hline 69 & $\mathrm{PGY}^{\mathrm{x}}$ & $G y /-$ & $\begin{array}{l}34 \\
28\end{array}$ & $\begin{array}{l}\text { All } \\
251\end{array}$ & 69 & 2.017 & 0.16 \\
\hline 14 & $\mathrm{SGY}^{\mathrm{w}}$ & $g y / g y$ & 14 & & All & & \\
\hline
\end{tabular}

${ }^{\mathrm{z}}$ For the $\mathrm{F}_{2}$ segregation data 69 and 14 , the $\chi_{3: 1}^{2}=2.928, P=0.09$.

${ }^{\mathrm{y}}$ For the $\mathrm{F}_{2}$ segregation data 34,28 , and 14 , the $\chi_{1: 2: 1}^{2}=15.79, P<0.001$.

${ }^{\mathrm{x}} \mathrm{PGY}=$ pale greenish yellow seedcoat.

${ }^{\mathrm{w}} \mathrm{SGY}=$ strong greenish yellow seedcoat . 
Table. 4. Segregation for seedcoat color and pattern in the $\mathrm{F}_{2}$ from the cross 'Wagenaar' $\left(C . J g b v^{\text {lae }} g y\right) \times C J g b v G y \mathrm{BC}_{3} 5-593$.

\begin{tabular}{|c|c|c|c|c|}
\hline \multirow{2}{*}{$\begin{array}{l}\text { No. of } \\
\text { plants }^{z}\end{array}$} & \multicolumn{4}{|c|}{ Seedcoat } \\
\hline & Phenotype $^{y}$ & & jenotyp & \\
\hline 20 & Violet, purple corona & $G y /-$ & $C / C$ & $v^{\text {lae }} /-$ \\
\hline 27 & Violet/PGY mottled, purple corona & $G y /-$ & $C / C^{\prime}$ & $v^{\text {lae }} /-$ \\
\hline 13 & Violet, PGY corona & $G y /-$ & $C / C$ & $v / v$ \\
\hline 4 & Violet/PGY mottled, PGY corona & $G y /-$ & $C / C^{\prime}$ & $v / v$ \\
\hline 7 & SGY, purple corona & $g y / g y$ & $-1-$ & $v^{\text {lae }} /-$ \\
\hline 9 & SGY, PGY corona & $g y / g y$ & $-1-$ & $v / v$ \\
\hline
\end{tabular}

${ }^{\mathrm{z} C o m b i n i n g ~ c l a s s e s ~ w i t h o u t ~ r e g a r d ~ f o r ~ t h e ~} C$ locus, the data 47, 17, 7, 9 give $\chi_{9: 3: 3: 1}^{2}=7.822, P=0.05$. The orthogonal contrasts are $\chi^{2}{ }_{\mathrm{Gy}}=1.067$, $P=0.30, \chi^{2}{ }_{\mathrm{V}}=2.400, P=0.12$, and $\chi_{\mathrm{L}}^{2}=4.356, P=0.037$; coupling linkage between $G y$ and $V$ is $35.51 \pm 6.938 \mathrm{cM}$.

yPG $=$ pale greenish yellow, $\mathrm{SGY}=$ strong greenish yellow.

the OAP12 ${ }_{1400}$ marker was determined to be $7.5 \mathrm{cM}$. To further test the independence of $G$ and the gene controlling the SGY phenotype, the $G$ segregating population was scored with the OAP12 1400 marker. The marker and the $G$ locus segregated independently. These molecular genetic tests lead us to the conclusion that the SGY phenotype derived from 'Wagenaar' is controlled by a genetic factor other than the $G$ locus. At this point, the inheritance of this trait was studied in more detail.

'WAgEnaAR' TEST CROSSES. 'Wagenaar' was crossed to a series of genetic tester stocks with known genotypes. The $F_{1}$ phenotypes $\left(\mathrm{F}_{2}\right.$ seed) are described below (Table 2$)$. The cross with $\mathrm{P}_{3}$ produced a marbled seedcoat with black and cartridge buff. The genetic interpretation is that 'Wagenaar' carries $C$ (See, Bassett, 2000, Table 3, class 5). The interpretation of the test cross with $\mathrm{P}_{3}$ is limited to determining that 'Wagenaar' does not carry $c^{\mathrm{u}}$ or the classic $c$ allele of Lamprecht (1932). The 'Wagenaar' $C$ gene, nevertheless, carries a linked mottling function, as will be presented and discussed below. The cross with $\mathrm{P}_{5}$ produced a surprising result (Table 2). The expected yellow brown color had a red haze, for which no hypothesis is pursued in this paper. The genetic interpretation is that 'Wagenaar' carries $r$. The test cross with $\mathrm{P}_{6}$ gave a nonallelic interaction, indicating that 'Wagenaar' carries $J$ (Table 2). The test crosses with $\mathrm{P}_{8}$ and $\mathrm{P}_{9}$ gave allelic interactions at $G$ and $B$, but not for the $V$ locus. The presence of purple corona color indicates that 'Wagenaar' carries $v^{\text {lae }}$. Thus, the genotype of 'Wagenaar' has been confirmed to be $C J g b v^{\text {lae }}$, which is in agreement of the findings of Prakken (1972). Only the finding of the red haze over yellow brown in the test cross with $\mathrm{P}_{5}$ is a new result. Prakken (1972) also established that 'Wagenaar' carries the gene $R k$ at the red kidney locus, and our results are consistent with that genotype.

The $\mathrm{F}_{1}$ from the cross 'Wagenaar' $\mathrm{x} g b v \mathrm{BC}_{3} 5-593\left(\mathrm{P}_{1} \times \mathrm{P}_{9}\right.$ of Table 2) produced the PGY (in light pattern color areas of the seedcoat) of $\mathrm{P}_{9}$. This result supports the hypothesis that the SGY of $\mathrm{P}_{1}$ is a recessive trait. The segregation for seedcoat color in the $F_{2}$ from the cross $P_{1} \times P_{9}$ fit a 3:1 ratio for PGY seedcoats to $S G Y$ seedcoats, respectively (Table 3 ). The data were consistent with the hypothesis that SGY is controlled by a single recessive gene.

$F_{3}$ TEST OF $\boldsymbol{G} \boldsymbol{y}$ HYPOTHESIS AND VARIABLE EXPRESSIVITY. The hypothesis of a single recessive-acting gene for SGY was tested in $F_{3}$. The $14 F_{2}$ parents with $S G Y$ seedcoat color were true breeding in $\mathrm{F}_{3}$ progenies (Table 3 ). The $28 \mathrm{~F}_{2}$ parents with PGY seedcoats that segregated for PGY and SGY seedcoats in $\mathrm{F}_{3}$ did so in a 3:1 ratio, respectively (Table 3 ). The remaining $34 F_{2}$ parents with PGY seedcoats were true breeding. The above three classes of $F_{3}$ progenies failed to fit the expected 1:2:1 ratio for true breeding SGY, segregating progenies, and true breeding PGY progenies (Table 3). The failure was due to an excess of true breeding PGY progenies. Low $\mathrm{F}_{2}$ seed yield probably prevented the accurate $\mathrm{F}_{3}$ characterization of some PGY $\mathrm{F}_{2}$ individuals as heterozygotes. The hypothesis that the SGY trait is controlled by a single recessive-acting gene is supported by two results from the $\mathrm{F}_{3}$ test: 1) the SGY class was true breeding and 2) a 3:1 segregation ratio for PGY and SGY, respectively, observed for the heterozygous $\mathrm{F}_{3}$ families.

We propose the gene symbol gy for the SGY trait. Although current rules for gene symbol nomenclature in common bean usually require three letters for the gene symbol, an exception was made to avoid making strings of gene symbols for seedcoat color genotypes any longer than necessary. The Genetics Committee of the Bean Improvement Cooperative has approved the gene symbol gy for SGY trait. We avoided using the gene symbol sgy for good reason. Although seeds with genotype $C J g b v$ have shamois color, in this paper we retained the name pale greenish yellow (PGY) in deference to the summary table of Prakken (1972). In a future revision of this table the color name for genotype $C J g b v$ should be changed to shamois only. Apparently, Lamprecht never reported observing a seed stock with $g y$ (Bassett, personal review of all Lamprecht papers), and Prakken never did genetic analysis with a seed stock having $C J g b v G y$. Besides 'Wagenaar', the only other stocks with $g b v^{\text {lae }}$ used by Prakken (1972) had $C^{\mathrm{m}}$ or $C^{\mathrm{st}}$ (both with $R$ expressed in the dark pattern areas).

The SGY character showed variable expressivity in the $F_{3}$

Table 5. Results of testcrosses between 'Enola' common bean and a series of genetic stocks with known genotypes.

\begin{tabular}{lll}
\hline & \multicolumn{2}{c}{ Phenotypes of flowers and seedcoats on $\mathrm{F}_{1}$ plants from the testcross } \\
\cline { 2 - 3 } Testcross & Flower & Seedcoat \\
\hline $\mathrm{P}_{2} \times \mathrm{P}_{7}$ & $\mathrm{C} . \mathrm{V}$. & Shiny black seed (no margo pattern) \\
$\mathrm{P}_{2} \times \mathrm{P}_{3}$ & $\mathrm{C} . \mathrm{V}$ & Dark mineral brown/cartridge buff marbling \\
$\mathrm{P}_{2} \times \mathrm{P}_{4}$ & P.P. & Yellow brown/cartridge buff marbling; no purple corona \\
$\mathrm{P}_{2} \times \mathrm{P}_{9}$ & P.P. & Violet/pale greenish yellow marbling; no purple corona \\
${ }^{\mathrm{z} T h e}$ names, phenotypes, and genotypes of the parental lines $\left(\mathrm{P}_{\mathrm{i}}\right)$ are given in Table 1. & \\
${ }^{y}$ C.V. = cobalt violet color expressed by $V / v^{\text {lae }}, \mathrm{P.P} .=$ pale pink expressed by $v^{\text {laa }} / v$. &
\end{tabular}


progenies derived from $\mathrm{SGY} \mathrm{F}_{2}$ parents. There was great variation from seed to seed within plants, from plant to plant within plots, and between plots for the frequency of extensively SGY colored seedcoats (data not presented). Although the data were not sufficient to develop a genetic model for the inheritance of higher and more stable expression of the SGY trait, the data suggested that other genetic factors may control higher expression levels.

For the cross 'Wagenaar' $\mathrm{x} g b v \mathrm{BC}_{3} 5-593$, the $\mathrm{F}_{1}$ progeny had mottled pale violet/PGY seedcoats (Table 2 ), and the $\mathrm{F}_{2}$ progeny segregated for the same phenotype (Table 4). This mottled phenotype was not expressed well in the $\mathrm{F}_{3}$ progeny grown in the field, and no data were recorded for mottling in that generation. Although 'Wagenaar' has the dominant $C$ gene (Table 2) (Bassett, 2000; Prakken, 1972), the mottling function (property) of the 'Wagenaar' $C$ is designated by the symbol $C$ ' (Table 4$)$. Interestingly, the mottling effect from $C$ ' does not express with $g y / g y$, and the SGY trait does not express (giving PGY by default) in the corona region with $g y / g y v / v$ (Table 4). Thus, with $g y / g y$ there is no seedcoat expression for the distinction between the $C / C$ and $C$ '/ $C^{\prime}$ genotypes (Table 4). Two possible interpretations are that $G y$ may be 1) linked to $C$ or 2 ) be an allele at $C$. Using the BAT 93 $x$ Jalo restriction fragment length polymorphism (RFLP) mapping system (Nodari et al., 1993), the sequence tagged site (STS) marker developed from the RAPD marker OAP12 1400 was mapped to linkage group B8, showing two map units between the $C$ and $G y$ loci (McClean, personal communication). Thus, the data support close linkage, but not allelism at $C$. Similar procedures with the same mapping system demonstrated that $V$ is located in linkage group B6. Hence, the weak linkage between $G y$ and $V$ of about $35 \mathrm{cM}$ (Table 4) was found to be artifactual (McClean, personal communication).

'ENOLA' TEST CROSSES AND RELATIONSHIP TO 'MAYOCOBA'. The cross $\mathrm{P}_{2} \times \mathrm{P}_{3}$ gave $\mathrm{F}_{2}$ seeds with dark mineral brown/cartidge buff marbling, which is interpreted as a $C$ gene in 'Enola' (Bassett, 2000) although a black/cartridge buff marbling is expected (Table 5). The cross $P_{2} \times P_{7}$ gave $F_{2}$ seeds with black color without pattern (a nonallelic response to the $j$ in the tester), which is interpreted as a $J$ gene in 'Enola' (Table 5). The cross $\mathrm{P}_{2} \times \mathrm{P}_{4}$ gave $\mathrm{F}_{2}$ seeds with yellow brown/cartridge buff marbling with no purple corona, which is an allelic response for $b$ and a nonalleleic response for $r k^{\mathrm{d}}$ and $r k$ (Table 5). Surprisingly, the cross $\mathrm{P}_{2} \times \mathrm{P}_{9}$ gave $\mathrm{F}_{2}$ seeds with violet/pale greenish yellow marbling and no purple corona, which is an allelic response for $g, b$, and $v$ (Table 5). No hypothesis for the violet color will be pursued in this paper. The pink flower color of 'Enola' indicates that 'Enola' carries $v^{\text {lae }}$ (Prakken, 1970). The cross $\mathrm{P}_{2} \times \mathrm{P}_{1}$ gave $\mathrm{F}_{2}$ seeds with $\mathrm{SGY}$ color, which is an allelic response indicating that 'Enola' also carries $g y$. Thus, the seedcoat genotype $C J g b v^{\text {lae }} R k g y$ for 'Enola' has been demonstrated.

'Enola' has pink flowers that are known to result from expression of the gene $v^{\text {lae }}$, but the seedcoat does not have the purple corona color produced pleiotropically by $v^{\text {lae }}$ (Bassett, 1995a; Prakken, 1970). Both the corona and hilum ring of 'Enola' are either SGY or PGY, whereas the hilum ring color produced by $C$ $J g b v$ is brown and by $C J g b v^{\text {lae }}$ is dark purple (Prakken, 1970). The test cross 'Enola' $x$ 'Wagenaar' produced $F_{2}$ seeds with SGY corona and hilum ring (data not presented). Similarly, the testcrosses $\mathrm{P}_{2} \times \mathrm{P}_{4}$ and $\mathrm{P}_{2} \times \mathrm{P}_{9}$ failed to show the expected purple corona, but, on the other hand, the flower color phenotypes for the four test crosses with 'Enola' support the hypothesis that $v^{\text {lae }}$ is present in 'Enola' (Table 5). Our hypothesis is that 'Enola' carries an unknown, dominant epistatic gene that suppresses the expected dark purple corona and brown hilum ring.

Both 'Enola' and 'Mayocoba' have the same SGY seedcoat color as 'Wagenaar,' and both cultivars express the same SGY color in the corona and hilum ring in the presence of gene $v^{\text {lae }}$. The test cross 'Wagenaar' $x$ 'Mayocoba' produced $F_{2}$ seeds with SGY color, purple corona, and brown hilum ring (data not presented). Thus, although 'Enola' and 'Mayocoba' both carry the gy gene for SGY, our hypothesis is that 'Mayocoba' carries an unknown, recessive epistatic gene that suppresses the expected dark corona and brown hilum ring in 'Mayocoba'. A full investigation of the interaction of $v^{\text {lae }}$ (and the $C$ and $J$ genes for hilum ring color) with both dominant and recessive epistatic suppressor genes is beyond the scope of this paper.

Comparison of the plant structure of 'Enola' and the 'Mayocoba' stock used in this paper showed that they were virtually indistinguishable (data not presented). These appearance similarities are consistent with the hypothesis that 'Enola' is a selection from one of the pure-line commercial cultivars of the 'Mayocoba' market class grown in Mexico for export to the United States market. In the 1960's, or by early 1970 at the latest, the land race Canario (same as U.S. 'Mayocoba' class) was sent from Peru to Mexico (O. Voysest, personal communication). This was the first time that 'Mayocoba' beans were introduced into Mexico. The Mexicans crossed 'Canario Divex 8120' X 'Canario 107' and released the derivative cultivar 'Azufrado Pimono 78 ' in 1978. This began a new commercial class in Mexico, which they designate "Peruano" (Voysest, 2000). In the early 1980's the name of 'Azufrado Pimono 78' was changed to 'Mayocoba'. This very popular Mexican cultivar name was, thereafter, used to denote the market class in the United States. More than five other Peruano cultivars were developed in Mexico after 'Mayocoba'. In 1987, Mexican bean breeder Ingeniero Salinas and colleagues released 'Azufrado Peruano 87', a Peruano class bean cultivar (Kelly, 2000). After the 'Enola' patent (Proctor, 1999) was issued, a biotechnology laboratory in Texacoco, Mexico, determined by DNA analysis of 'Enola' (seeds obtained from the U.S. Patent Office) that 'Enola' was derived from 'Azufrado Peruano 87' (Kelly, 2000).

The patent for 'Enola' (Proctor, 1999) claims that "Enola seeds possess a unique yellow color...", but the results given above demonstrate that the well-known 'Wagenaar' bean cultivar, as well as all the Peruano market class cultivars of Mexico, have the same seedcoat color. When 'Enola' and 'Mayocoba' are grown together in the same greenhouse in Gainesville, the SGY seedcoat color of both cultivars is strongly expressed and covers the entire seedcoat of nearly all seeds when plants mature in December; but when the same cultivars mature together in March, the seedcoat color is distributed incompletely on the seedcoat and is weaker in expression. This seasonal variation is also typical of 'Wagenaar' when grown in greenhouse culture and is typical for a trait with varible expressivity. The 'Enola' patent (Proctor, 1999) also claims that the yellow color of the seed remains uniform and stable from season to season., but our results do not support that claim. The 'Enola' patent (Proctor, 1999) makes an exclusive property claim to all bean cultivars with the seedcoat color of 'Enola' (referred to as SGY in this paper) based on "invention" of that seedcoat color, but we assert that the program (described in the patent) of several successive cycles of self-pollination and selection from yellow bean materials purchased in Mexico did not create or invent the seedcoat color of 'Enola', i.e., the "invention" has no basis in fact. 


\section{Literature Cited}

Allard, R.W. 1956. Formulas and tables to facilitate the calculation of recombinational values in heredity. Hilgardia 24:235-278.

Bassett, M.J. 1994. The genotype for seedcoat color of breeding line 5593. Annu. Rpt. Bean Improvement Coop. 37:244-245.

Bassett, M.J. 1995a. The dark corona character in seedcoats of common bean cosegregates with the pink flower allele $v^{\text {lae }}$. J. Amer. Soc. Hort. Sci. 120:520-522.

Bassett, M.J. 1995b. A new recessive allele at the $C$ locus for seedcoat color in common bean. J. Amer. Soc. Hort. Sci. 120:896-899.

Bassett, M.J. 1996a. The margo ( $m a r$ ) seedcoat color gene is a synonym for the Joker ( $j$ ) locus in common bean. J. Amer. Soc. Hort. Sci. 121:1028-1031.

Bassett, M.J. 1996b. A complex $C$ region genotype [? $R$ ] that with $G B$ $v^{\text {lae }}$ produces dark seal-brown seedcoat color in common bean. J. Amer. Soc. Hort. Sci. 121:594-598.

Bassett, M.J. 2000. A test cross protocol for determining the seedcoat genotype at the $C$ locus in common bean. HortScience 35:286-289.

Bassett, M.J. and A. Blom. 1991. A new genotype for white seed coat discovered in 'Early Wax' snap bean. J. Amer. Soc. Hort. Sci. 116:131136.

Brady, L., M.J. Bassett, and P.E. McClean. 1998. Molecular markers associated with $T$ and $Z$, two genes controlling partly colored seed coat patterns in common bean. Crop Sci. 38:1073-1075.

Kelly, J.D. 2000. Enola yellow bean patent. Michigan Dry Bean Dig. 24(3):2-3.

Lamprecht, H. 1932. Beiträge zur Genetik von Phaseolus vulgaris. Zur Vererbung der Testafarbe. Hereditas 16:169-211.

Mather, K. 1957. The measurement of linkage in heredity. 2nd ed. Wiley, New York.

Nodari, R.O., S.M. Tsai, R.L. Gilbertson, and P. Gepts. 1993. Towards an integrated linkage map of common bean. II. Development of an RFLP-based linkage map. Theor. Appl. Genet. 85:513-520.

Prakken, R. 1940. Inheritance of colours in Phaseolus vulgaris L. I. Genetica 22:331-408.

Prakken, R. 1970. Inheritance of colour in Phaseolus vulgaris L. II. A critical review. Meded. Landbouwhogeschool Wageningen 70-23:138.

Prakken, R. 1972. Inheritance of colours in Phaseolus vulgaris L. III. On genes for red seedcoat colour and a general synthesis. Meded. Landbouwhogeschool Wageningen, 72-29.

Proctor, L.M. 1999. Field bean cultivar named Enola. U.S. Patent No. 5,894,079 (13 Apr. 1999). U.S. Patent and Trademark Office, Wash., D.C.

Voysest, O. 2000. Yellow beans in Latin America. Michigan Dry Bean Dig. 24(3):4-8. 